Acta vet. scand. 1988, 29, 219-223.

From the National Veterinary Institute, Department of Pathology, Veterinary College, Swedish University of Agricultural Sciences, Uppsala, and Department of Biochemistry and Biotechnology, Royal Institute of Technology, Stockholm, Sweden.

\title{
Ochratoxin A as a Suppressor of Mitogen-Induced Blastogenesis of Porcine Blood Lymphocytes
}

\author{
By Torbjörn Holmberg, Ann Thuvander and Karl Hult
}

\begin{abstract}
Holmberg, T., A. Thuvander and K. Hult: Ochratoxin A as a suppressor of mitogen-induced blastogenesis of porcine blood lymphocytes. Acta vet. scand. 1988, 29, 219-223. - The in vitro effect of ochratoxin A on pig lymphocytes stimulated by the mitogen Concanavalin A was studied by measuring the rates of ${ }^{3} \mathrm{H}$-thymidine incorporation in DNA.

Ochratoxin A inhibited the mitogenic response to Concanavalin $\mathrm{A}$ in a dose dependent way. An almost total inhibition was obtained with $\geq 1 \mathrm{mg}$ ochratoxin $\mathrm{A} / 1$, approximately $60 \%$ inhibition was produced by $0.5 \mathrm{mg}$ ochratoxin $\mathrm{A} / 1$ and approximately $10 \%$ inhibition by $0.06 \mathrm{mg}$ ochratoxin $\mathrm{A} / 1$.

The immunosuppressive effect of ochratoxin A was not altered much by different contents of bovine serum albumin, 0.1 or $0.3 \%$, in the cell culture medium.
\end{abstract}

immunosuppression; lymphoblastogenesis; pigs.

\section{Introduction}

Ochratoxin A, a fungal metabolite produced by several species of Aspergillus and Penicillium, has a well documented nephrotoxic effect (Krogh 1978) causing. spontaneous nephropathy in pigs and chickens. Ochratoxin A also causes immunosuppression (Szczech et al. 1973a, b, Prior \& Sisodia 1982, Dwivedi \& Burns 1984). Even single parenteral administration of a low dose of ochratoxin A to mice reduced their antibody response to sheep erythrocytes (Haubeck et al. 1981, Creppy et al. 1983). Haubeck et al. (1981) suggest that ochratoxin A at levels found in blood of slaughter pigs (for a review see Hult \& Fuchs, 1986) have a negative effect on the pig's immune system.

Inhibition of the lymphocyte blastogenesis is a valid in vitro model for determining the effect of environmental contaminants on immunocompetent cells (Kristensen et al. 1982) and has been used to study the effect of mycotoxins on blood lymphocytes (Paul et al. 1977, Cooray 1984, Forsell \& Pestka 1985). In the present study we used the lymphocyte stimulation test to elucidate the immunosuppressive effect of ochratoxin A on lymphocytes obtained from young growing pigs.

\section{Materials and methods}

Animals

From a litter of 3 months old special pathogen free (SPF) pigs, clinically healthy and housed under strict isolation conditions, 6 animals were randomly selected and used as blood donors. 


\section{Ochratoxin A}

A strain of Penicillium nordicum was cultivated on barley for 2 weeks at $25^{\circ} \mathrm{C}$. Crystalline ochratoxin A was prepared from the culture according to the method for extraction and purification described by Fuchs et al. (1984).

\section{Lymphocyte stimulation test}

Peripheral blood lymphocytes were isolated from heparinized venous blood. Blood samples were diluted with an equal volume of RPMI 1640 cell culture medium, pH 7.4, carefully layered on a caushion of Ficoll-Paque $(\mathrm{d}=1.077 \mathrm{~g} / \mathrm{ml}$; Pharmacia, Uppsala, Sweden) and centrifuged for $25 \mathrm{~min}$ at 400 g. The cells from the interface were collected and washed 3 times in phosphate buffer saline $(0.01 \mathrm{~mol} / \mathrm{l}$ sodium phosphate, $0.85 \%$ sodium chloride, $\mathrm{pH}$ 7.2). The cell pellet was resuspended in RPMI 1640 supplemented with $20 \mathrm{mmol} / 1 \mathrm{HEPES}, 2 \mathrm{mmol} / 1$ gluta$\mathrm{min}, 200 \mathrm{IU} / \mathrm{ml}$ penicillin and $200 \mu \mathrm{g} / \mathrm{ml}$ streptomycin.

The cells were cultured in plastic tubes at $1 \times 10^{6}$ cells per tube in a volume of $1 \mathrm{ml}$. The mitogen Concanavalin A (Con A) was added at a final concentration of $2.5 \mu \mathrm{g} / \mathrm{ml}$ to all tubes except for the negative control cultures. Ochratoxin A, diluted in RPMI 1640 medium, was added at concentrations between $0.06-4 \mathrm{mg} / \mathrm{ml}$ to the cultures with Con A.

The various cell cultures were incubated for 3 days at $37^{\circ} \mathrm{C}$, whereupon $1 \mu \mathrm{Ci}{ }^{3} \mathrm{H}$-thymidine was added. After another $24 \mathrm{~h}$ of incubation, the cells were harvested with a semiautomatic cell culture harvester on glass microfiber filters and were dried and transferred to vials containing scintillation liquid (Lipo Luma/3 M bv, The Netherlands) The ${ }^{3} \mathrm{H}$ activity of each culture was measured in a liquid scintillation counter (Minaxi, Tricarb $4000 \beta$-counter, United Technologies, Packard Instruments). All results were expressed as the average counts per minute (cpm) of triplicate cultures. The stimulation index (SI) was calculated according to the formula:

$$
\mathrm{SI}=\frac{\text { Mean } \mathrm{cpm} \text { of the Con A stimulated cultures }}{\text { Mean cpm of the negative control cultures }}
$$

The percentage of inhibition (IH \%) of DNA synthesis exerted by ochratoxin A was calculated according to the formula:

$$
\text { IH } \%=100-\frac{\text { mean cpm of Con A stimulated cultures with ochratoxin A } \times 100}{\text { mean cpm of Con A stimulated cultures without ochratoxin A }}
$$

\section{Medium supplement}

The assay was performed with 2 different concentrations of bovine serum albumin (BSA) in the medium. Therefore, RPMI 1640 cell culture medium was supplemented with $10 \%$ fetal calf serum (FCS) or $2 \%$ Ultroser G (LKB, Solna, Sweden). Analysis of the serum albumin content in FCS and Ultroser $G$ was performed at the Department of Clinical Chemistry, Swedish University of Agricultural Sciences, Uppsala, Sweden.

\section{Results}

The blood lymphocytes responded to Con A with SI values ranging from 18 to 101 in cultures supplemented with FCS (extremes from animals not shown in Table 1) and with SI from 69 to 134 in cultures supple- 
Tabel 1. The effect of ochratoxin A on mitogen (Con A) stimulated porcine blood lymphocytes cultured in medium supplemented with $10 \%$ fetal calf serum (FCS; $0.3 \%$ BSA in the medium) or with $2 \%$ Ultroser G (0.1\% BSA in the medium). The results represent 3 different animals and the standard deviation (SD) of triplicate cultures from each animal. ND = not done.

\begin{tabular}{|c|c|c|c|c|c|c|c|}
\hline \multirow{3}{*}{$\begin{array}{l}\text { Medium } \\
\text { supplement }\end{array}$} & \multirow{3}{*}{$\begin{array}{l}\text { Ochratoxin A } \\
\mathrm{mg} / 1\end{array}$} & \multicolumn{6}{|c|}{ Animal } \\
\hline & & \multicolumn{2}{|l|}{ no. 10} & \multicolumn{2}{|l|}{ no. 12} & \multicolumn{2}{|l|}{ no. 16} \\
\hline & & $\begin{array}{c}3^{3} \mathrm{H} \text {-thymidine } \\
\mathrm{cpm} \times 1000 \pm \mathrm{SD}\end{array}$ & SI & $\begin{array}{c}\text { 3H-thymidine } \\
\mathrm{cpm} \times 1000 \pm \mathrm{SD}\end{array}$ & SI & $\begin{array}{c}\text { 3H-thymidine } \\
\mathrm{cpm} \times 1000 \pm \mathrm{SD}\end{array}$ & SI \\
\hline FCS & 0 & $7 \pm 2$ & 1 & $4 \pm 0.4$ & 1 & $4 \pm 3$ & 1 \\
\hline \multirow[t]{8}{*}{$\mathrm{FCS}+\mathrm{Con} \mathrm{A}$} & 0 & $341 \pm 21$ & 49 & $152 \pm 10$ & 38 & $181 \pm 24$ & 45 \\
\hline & 0.06 & $312 \pm 23$ & 45 & ND & - & ND & - \\
\hline & 0.12 & $311 \pm 41$ & 44 & ND & - & ND & - \\
\hline & 0.25 & $295 \pm 23$ & 42 & $118 \pm 23$ & 29 & $103 \pm 13$ & 26 \\
\hline & 0.5 & $203 \pm 32$ & 29 & $53 \pm 4$ & 13 & $66 \pm 27$ & 16 \\
\hline & 1 & $46 \pm 18$ & 7 & $12 \pm 2$ & 3 & $5 \pm 0.7$ & 1 \\
\hline & 2 & $2 \pm 1$ & 0.3 & $1 \pm 0.5$ & 0.2 & $1 \pm 0.0$ & 0.2 \\
\hline & 4 & ND & - & $0.7 \pm 0.3$ & 0.2 & $0.4 \pm 0.1$ & 0.1 \\
\hline Ultroser G & 0 & $3 \pm 0.9$ & 1 & $2 \pm 0.3$ & 1 & $1 \pm 0.6$ & 1 \\
\hline \multirow{8}{*}{$\begin{array}{l}\text { Ultroser G + } \\
\text { Con A }\end{array}$} & 0 & $208 \pm 15$ & 69 & $227 \pm 12$ & 113 & $134 \pm 12$ & 134 \\
\hline & 0.06 & $184 \pm 25$ & 61 & ND & - & ND & - \\
\hline & 0.12 & $159 \pm 9$ & 53 & ND & - & ND & - \\
\hline & 0.25 & $141 \pm 14$ & 47 & $151 \pm 31$ & 75 & $102 \pm 13$ & 102 \\
\hline & 0.5 & $103 \pm 5$ & 34 & $62 \pm 4$ & 31 & $42 \pm 6$ & 42 \\
\hline & 1 & $2 \pm 2$ & 0.7 & $2 \pm 1$ & 1 & $0.9 \pm 0.4$ & 0.9 \\
\hline & 2 & $0.4 \pm 0.0$ & 0.1 & $0.5 \pm 0.1$ & 0.2 & $0.4 \pm 0.2$ & 0.4 \\
\hline & 4 & ND & - & $0.4 \pm 0.1$ & 0.2 & $1 \pm 0.2$ & 1 \\
\hline
\end{tabular}

mented with Ultroser G. The addition of ochratoxin A resulted in an inhibition of the mitogen induced lymphoblastogenesis as measured by ${ }^{3} \mathrm{H}$-thymidine incorporation in the cells. The inhibition was dose dependent compared with stimulated cultures without ochratoxin A (Fig. 1). An almost total inhibition (95-100\%) was observed with concentrations of ochratoxin $A \geq 1 \mathrm{mg} / \mathrm{l}$. Approximately $60 \%$ and $10 \%$ inhibition of the lymphocyte response was noticed with 0.5 and $0.06 \mathrm{mg}$ ochratoxin $\mathrm{A} / 1$, respectively.

The serum albumin content in FCS and Ultroser $\mathrm{G}$ was 30 and $57 \mathrm{~g} / 1$ respectively. The addition of $10 \%$ FCS or $2 \%$ Ultroser $G$ to the culture medium gave final BSA-concen- trations of $0.3 \%$ or $0.1 \%$ respectively. No marked difference in inhibition of lymphoblastogenesis caused by ochratoxin A was seen between cultures supplemented with FCS or Ultroser G (Table 1). Only a tendency to higher immunosuppression by ochratoxin A was noticed for cultures supplemented with less BSA (Ultroser G).

\section{Discussion}

Ochratoxin A is known to act in a nonselective immunosuppressive manner causing both reduction in the number of antibody forming cells in lymfoid organs (Prior \& Sisodia 1982) and reduction of total immunoglobulin levels (Creppy et al. 1983, 


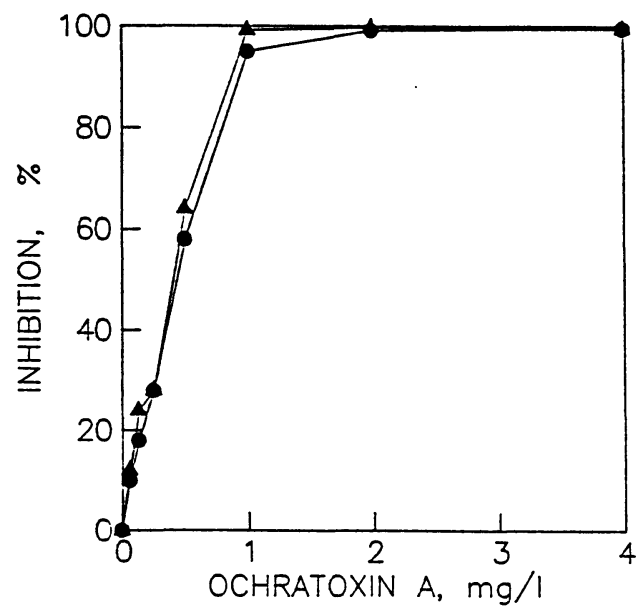

Figure 1. The inhibitory effect of different doses of ochratoxin A on the response of lymphocytes obtained from SPF-pigs to Concanavalin $\mathrm{A}$ as measured by ${ }^{3} \mathrm{H}$-thymidine incorporation.

(๑) \% inhibition in cultures supplemented with fetal calf serum (means from 6 animals).

(৯) \% inhibition in cultures supplemented with Ultroser $\mathrm{G}$ (means from 3 animals).

Dwivedi \& Burns 1984). This mode of action is probably due to the strong inhibition of protein synthesis demonstrated for ochratoxin A (Röschenthaler et al. 1984).

In the present experiment the effect of ochratoxin A on in vitro stimulated porcine blood lymphocytes was studied. The mitogen used, Con A, mainly stimulates the thymus derived $(\mathrm{T})$ lymphocytes. Our findings demonstrated the capacity of ochratoxin A to bring about a dose dependent in vitro inhibition of cell mediated immune response in the pig. Using higher concentrations of ochratoxin A similar immunosuppressive effects have been reported for mitogen stimulated lymphocytes from mice (Prior \& Sisodia 1982) and humans (Cooray 1984).

Ochratoxin A binds to BSA (Chu 1971). We therefore compared media supplemented with either $10 \%$ FCS or $2 \%$ Ultroser G, giving different final BSA contents in the media, $0.3 \%$ or $0.1 \%$ respectively. According to Chu (1971) this difference in BSA concentration changed the ratio between the free and the bound forms of the toxin so that the concentration of free ochratoxin $\mathrm{A}$ in the low BSA medium was twice that in the high BSA medium. The immunosuppressive effect of ochratoxin A was, however, not much affected by the higher BSA-content in the cell culture medium. Therefore, our study indicates that immunosuppression caused by ochratoxin A is not only a function of the amount of free toxin present for the cells. This is in accordance with other studies (Haubeck et al. 1981, Creppy et al. 1983) where potent immunosuppressive effects of low doses of ochratoxin $\mathrm{A}$ in mice have been demonstrated despite the possibility for ochratoxin A to bind to serum albu$\min$.

Our experiment was carried out using a limited number of young pigs. Nevertheless the result is interesting because it indicates that the pig's immune system is sensitive even to doses of ochratoxin A considerably lower than $1 \mathrm{mg} / \mathrm{l}$. From the dose-response graph (Fig. 1) it can be seen that a $10 \%$ inhibition of the lymphocyte response occurs at approximately $0.06 \mathrm{mg}$ ochratoxin $\mathrm{A} / 1$, a level of ochratoxin A which is naturally found in the blood of slaughter pigs (Hult et al. 1980, Hult et al. 1984). As a consequence of this fact the long time effects in pigs exposed to ochratoxin A blood levels of 0.06 $\mathrm{mg} / \mathrm{l}$ or even lower need to be evaluated. Under practical farming conditions a $10 \%$ inhibition of the immune response might have a great relevance to the health of the pigs.

\section{Acknowledgement}

This work was supported by grants from the Swedish Council for Forestry and Agricultural Research and from the Foundation of Veterinary Feed Control. 


\section{References}

Chu FS: Interaction of ochratoxin A with bovine serum albumin. Archs. Biochem. Biophys. 1971, 147, 359-366.

Cooray R: Effects of some mycotoxins on mitogen induced blastogenesis and SCE frequency in human lymphocytes. Fd. Chem. Toxic. 1984, 22, 529-534.

Creppy EE, Störmer FC, Röschenthaler R, Dirheimer $G$ : Effects of two metabolites of ochratoxin A, (4R)-4-hydroxyochratoxin $A$ and ochratoxin $\alpha$ on immune response in mice. Infect. Immun. 1983, 39, 1015-1018.

Dwivedi P, Burns RB: Effect of ochratoxin A on immunoglobulins in broiler chicks. Res. Vet. Sci. 1984, 36, 117-121.

Forsell JH, Pestka JJ: Relation of 8-ketotrichothecene and zearalenone analog structure to inhibition of mitogen-induced human lymphocyte blastogenesis. Appl. Environ. Microbiol. 1985, 50, 1304-1307.

Fuchs $R$, Hult K, Peraica M, Radic B, Plestina $R$ : Conversion of ochratoxin $C$ into ochratoxin A in vivo. Appl. Environ. Microbiol. 1984, 48, 41-42.

Haubeck H-D, Lorkowski G, Kölsch E, Röschenthaler $R$ : Immunosuppression by ochratoxin $\mathrm{A}$ and its prevention by phenylalanine. Appl. Environ. Microbiol. 1981, 41, 1040-1042.

Hult $K$, Hökby E, Gatenbeck S, Rutqvist L: Ochratoxin A in blood from slaughter pigs in Sweden: use in evaluation of toxin content of consumed feed. Appl. Environ. Microbiol. 1980, 39, 828-830.

Hult $\mathrm{K}$, Rutqvist L, Holmberg $T$, Thafvelin $\mathrm{B}, \mathrm{Ga}$ tenberg $S$ : Ochratoxin A in blood of slaughter pigs. Nord. Vet. Med. 1984, 36, 314-316.

Hult $K$, Fuchs $R$ : Analysis and dynamics of ochratoxin A in biological systems. In Mycotoxins and phycotoxins. P. S. Steyn \& R. Vleggaar (Eds.) Elsevier, Amsterdam, 1986, 365-376.

Kristensen F, Kristensen B, Lazary S: The lymphocyte stimulation test in veterinary immunology. Vet. Immunol. Immunopathol. 1982, 3, 203-277.
Krogh P: Causal associations of mycotoxic nephropathy. Thesis. Acta path. microbiol. scand. Sect. A Suppl. 1978, 269.

Paul PS, Johnsson DW, Mirocha CJ, Soper FF, Thoen CO, Muscoplat GG, Weber AF: In vitro stimulation of bovine peripheral blood lymphocytes: Suppression of phytomitogen and specific antigen lymphocyte responses by aflatoxin. Amer. J. Vet. Res. 1977, 38, 2033-2035.

Prior MG, Sisodia CS: The effects of ochratoxin $A$ on the immune response of swiss mice. Can. J. comp. Med. 1982, 46, 91-96.

Röschenthaler R, Creppy EE, Dreismann H, Dirheimer G: Ochratoxin A - on the mechanism of action. In Toxigenic fungi - their toxins and health hazard. Proc. Mycotox. Symp. 3rd Internat. Mycol. Congr. Tokyo Aug 30-Sep 3 1983, Kurata, H. \& Ueno Y. (Eds.) Elsevier Kodansha Tokyo 1984, 255-264.

Szczech GM, Carlton WW, Tuite J: Ochratoxicosis in Beagle dogs II. Pathology. Vet. Pathol. 1973a, 10, 219-231.

Szczech GM, Carlton WW, Tuite J \& Caldwell R: Ochratoxin A Toxicosis in Swine. Vet. Pathol. 1973b, 10, 347-364.

\section{Sammanfattning}

Ochratoxin A som hämmare af mitogen-

inducerad blastogenes av lymfocyter från grisar.

Effekten in vitro av ochratoxin A på stimulering av grislymfocyter med mitogenet Concanavalin $\mathrm{A}$ studerades genom att mäta mängden ${ }^{3} \mathrm{H}$-thymidin som inkorporerades i lymfocyternas DNA.

Ochratoxin A hämmade mitogeneffekten av Concanavalin $\mathbf{A}$ på ett dosrelaterat sätt. En nästan total inhibering erhölls med $\geq 1 \mathrm{mg}$ ochratoxin $\mathrm{A} / 1$, ungefär $60 \%$ inhibering åstadkoms med 0,5 mg ochratoxin $\mathrm{A} / 1$ och ungefär $10 \%$ inhibering med $0,06 \mathrm{mg}$ ochratoxin $\mathrm{A} / 1$.

Den immunosuppressiva effekten av ochratoxin A påverkades inte i nämnvärd omfattning av olika mängder av bovint serum albumin, 0,1 eller $0,3 \%$, i cellodlingsmediet.

\section{(Received December 7, 1987).}

Reprints may be requested from: Torbjörn Holmberg, National Veterinary Institute, P. O. Box 7073, S-750 07 Uppsala, Sweden. 
